Gut, 1980, 21, 745-749

\title{
Release of vasoactive intestinal peptide by distention of the proximal stomach in dogs*
}

\author{
J-A CHAYVIALLE, $\dagger$ M MIYATA, $\ddagger$ P L RAYFORD, AND J C THOMPSON \\ From the Department of Surgery, The University of Texas Medical Branch, Galveston, Texas, USA
}

SUMMARY The effect of transient proximal gastric distention was studied in six conscious dogs previously submitted to antrectomy and Billroth I anastomosis (and in which the intragastric $\mathrm{pH}$ was not altered), and in five anaesthetised dogs prepared with an innervated acute fundic pouch in which the pouch lumen was acidified with $0 \cdot 15 \mathrm{M}$ hydrochloric acid. Levels of vasoactive intestinal peptide (VIP) in portal and peripheral plasma were measured by radioimmunoassay. In conscious antrectomised dogs, distention of the proximal stomach to volumes of 250 and $500 \mathrm{ml}$ evoked a significant rise of portal VIP concentration, with a maximal variation of $32 \cdot 7 \pm 4.4$ to $67 \cdot 7 \pm 14 \cdot 8$ $\mathrm{pg} \mathrm{ml}^{-1}$, which was hardly reflected in systemic blood. In the anaesthetised dogs, transient distention of the acute fundic pouch with $0.15 \mathrm{M}$ hydrochloric acid under a pressure of $40 \mathrm{~cm}$ of water elicited a significant rise of portal VIP from $36.2 \pm 8.9$ to $59.8 \pm 12.4 \mathrm{pg} \mathrm{ml}^{-1}(\mathrm{P}<0.05)$ without any significant variation of the peptide concentration in peripheral plasma. These results indicate that vasoactive intestinal peptide is released under transient proximal gastric distention in dogs, and that this response is not solely dependent upon the acid secretory effect of distention in this species.

Vasoactive intestinal peptide (VIP), an octacosapeptide characterised from porcine upper intestine, ${ }^{1}$ is widely distributed in the central nervous system, digestive tract, and urogenital tract. ${ }^{23}$ Gastrointestinal VIP is detected at immunocytochemistry both in mucosa and muscular layers. ${ }^{24}$ Releasing factors so far identified include intraduodenal fatty acid ${ }^{5}$ or hyperosmolar solutions, ${ }^{5-7}$ intravenous calcium infusion, ${ }^{8}$ and vagal stimulation. ${ }^{9}$ Recently, mechanical stimulation of the oesophagus and colon was found to induce a significant release of VIP in anaesthetised (atropinised) cats. ${ }^{9}$

The present study was undertaken to assess the effect of proximal gastric distention on portal and peripheral plasma VIP concentrations in dogs.

\section{Methods}

Two experimental groups were studied. Under Nembutal anaesthesia, six dogs $(22-28 \mathrm{~kg}$ at the

\footnotetext{
*Presented in part at the 2nd International Symposium on Gastrointestinal Hormones, Beito, Norway, August 1978. A preliminary abstract has appeared. Supported by grants from the National Institutes of Health (AM 15241) and the John A Hartford Foundation, Inc.

†Present address: Hôpital Edouard-Herriot, Lyon, France.

¥Present address: Osaka University Medical School, Osaka, Japan.

Received for publication 5 February 1980
}

time of the test) were submitted to antrectomy and Billroth I anastomosis. After a recovery period of at least three weeks, a gastric fistula was constructed with a Thomas cannula, and an indwelling portal catheter was positioned via a splenic vein tributary. The tests were started at least eight days after this second operation. All animals showed normal gastric emptying, and could easily ingest $400 \mathrm{ml}$ canned dog food plus water three times a day.

After an 18-hour fast without water restriction, the gastric fistula was opened and rinsed with distilled water. A rubber balloon, connected to a thin catheter for inflation, was positioned into the stomach. A second catheter was secured along this, so as to permit intragastric infusion of phenol red $\left(8 \mathrm{mg} 1^{-1}, \mathrm{pH} \mathrm{7.0)}\right.$ at a rate of $180 \mathrm{ml} \mathrm{h}^{-1}$. Care was taken to keep the gastric fistula patent. The gastric contents were continuously collected by gravity drainage. A catheter was positioned in a hindleg vein and kept patent with a slow infusion of isotonic saline. Saline was used as well for intermittent flushing of the portal catheter which was connected to a three-way stopcock. After $\mathbf{3 0}$ minutes of recovery, the balloon was intermittently inflated with 125,250 , and $500 \mathrm{ml}$ of air in random order. No side-effect of distention was observed, except nausea in one dog for the $500 \mathrm{ml}$ distention. 
Each inflation period, lasting for five minutes, was preceded by a 10 minute basal period and followed by 30 minutes of recovery. Blood samples $(3 \mathrm{ml})$ were taken simultaneously via portal and peripheral catheters at regular intervals. The gastric effluent was collected as $\mathbf{1 0}$ minute fractions and the volume was measured to the nearest $0.1 \mathrm{ml}$. The concentration of phenol red was estimated on a Beckman spectrophotometer at 520,560 and $600 \mathrm{~nm}$ for correction of non-specific absorbance in coloured samples, ${ }^{10}$ and was used to calculate the recovery of gastric contents. The acid concentration was measured by titrating $1 \mathrm{ml}$ aliquots with $0 \cdot 1 \mathrm{M}$ $\mathrm{NaOH}$, using phenol red as indicator. The acid output was calculated from volume and acid concentration, and corrected from the percentage of marker recovered during the corresponding 10 minute period.

The effect of gastric distention against luminal acidification was studied in five dogs $(24-31 \mathrm{~kg})$ under Nembutal anaesthesia. Through a mid-line laparotomy, a fundic pouch was prepared with two long intestinal clamps. Care was taken to preserve the vascular and nervous connections of the pouch. Three Foley catheters were inserted, two for infusion into and drainage from the pouch and one for gravity drainage of the isolated fundus above the proximal clamp. Venous catheters were positioned respectively in the portal vein, in one of the fundic veins, and in a hindleg vein. The peripheral catheter was kept patent with a slow infusion of isotonic saline and the portal catheter was flushed at intervals with the same solution. In order to prevent venous stasis in the wall of the pouch, the catheter in the fundic vein was left open throughout the test, with a blood loss of $0.5-2 \mathrm{ml} / \mathrm{min}$. The dogs were allowed to recover for one hour before starting the experiment. The pouch was continuously irrigated with $0.15 \mathrm{M}$ hydrochloric acid at a rate of $180 \mathrm{ml} \mathrm{h}^{-1}$. The acid solution was used for intermittent distention of the pouch to pressures of 10,20, and $40 \mathrm{~cm}$ of water in sequential order. Each distention was applied for five minutes, followed by gravity drainage of the pouch, and the irrigation was resumed until the next distention period. The pouches accomodated about $200 \mathrm{ml}$ liquid under the $40 \mathrm{~cm}$ of water pressure. Blood samples were collected simultaneously from portal, fundic, and peripheral catheters.

Blood samples were collected in Trasylol $(800$ $\mu / \mathrm{ml})$ and heparin $(8 \mu / \mathrm{ml})$ in ice-chilled glass tubes. The plasma VIP concentration was measured with a radioimmunoassay previously described.11 Antiserum 76A, used at a 1:200000 final dilution, recognises the 18-28 portion of porcine VIP (gift from Professor M Bodansky), but shows full reactivity only with the entire molecule. Porcine VIP (gift from Professor V Mutt) was used as standard and for iodination with ${ }^{125} \mathrm{I}$ using lactoperoxydase (B grade, Calbiochem, San Diego, Ca). Samples from each dog were tested against a standard curve prepared in $20 \%$ charcoal-treated plasma. Unknown samples and peptide-free plasma were acidified to $\mathrm{pH} 5.5-6.0$ with $0.4 \mathrm{M}$ acetic acid before incubation. The within-assay and between-assay variations of the system are less than $10 \%$. The sensitivity of the assay is 7.5 to $15 \mathrm{pg} / \mathrm{ml}$ of plasma. The recovery of 2-16 pg VIP per tube is $80-100 \% .^{11}$ Results were expressed as pg equivalents of porcine VIP per ml plasma. Student's $t$ test for paired values was used for statistical analysis; $P$ values of less than 0.05 were considered to be significant.

\section{Results}

In conscious dogs, fundic distention with air induced significant rises in portal VIP; levels rose from a mean basal value of $31.5 \pm 4.5$ to $47.0 \pm$ $9.3 \mathrm{pg} \mathrm{ml}^{-1}$ with $250 \mathrm{ml}$ distention and from $32.7 \pm 4.4$ to $67.7 \pm 14.8 \mathrm{pg} \mathrm{ml}^{-1}$ with $500 \mathrm{ml}(\mathrm{P}<0.05$, Fig. 1). The variation induced by inflation with

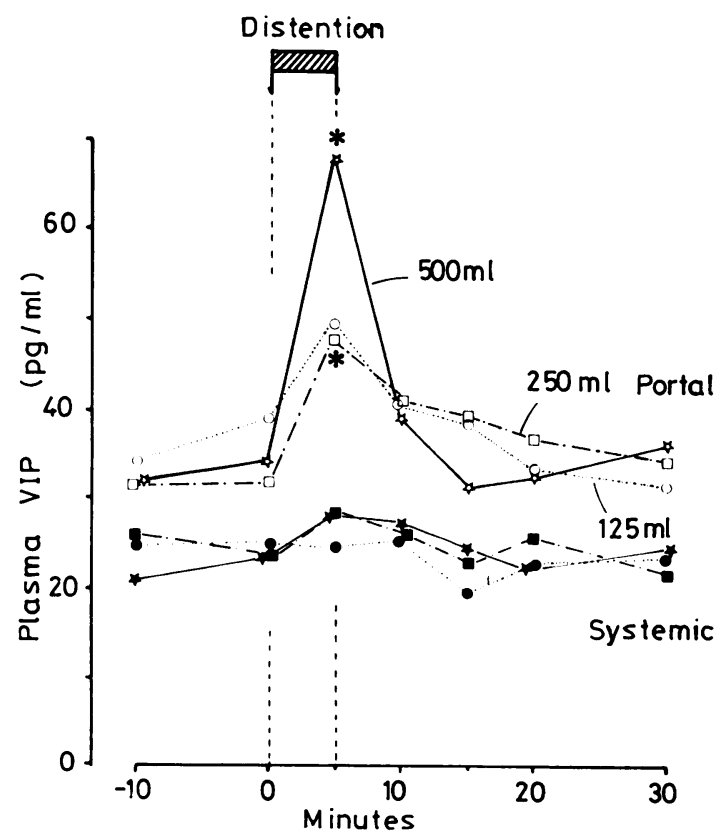

Fig. 1 Effect of five minute gastric distention with a balloon inflated with 125, 250, and $500 \mathrm{ml}$ of air on portal (open symbols) and peripheral (full symbols) plasma VIP concentrations in six antrectomised dogs. $* \mathrm{P}<0.05$. 

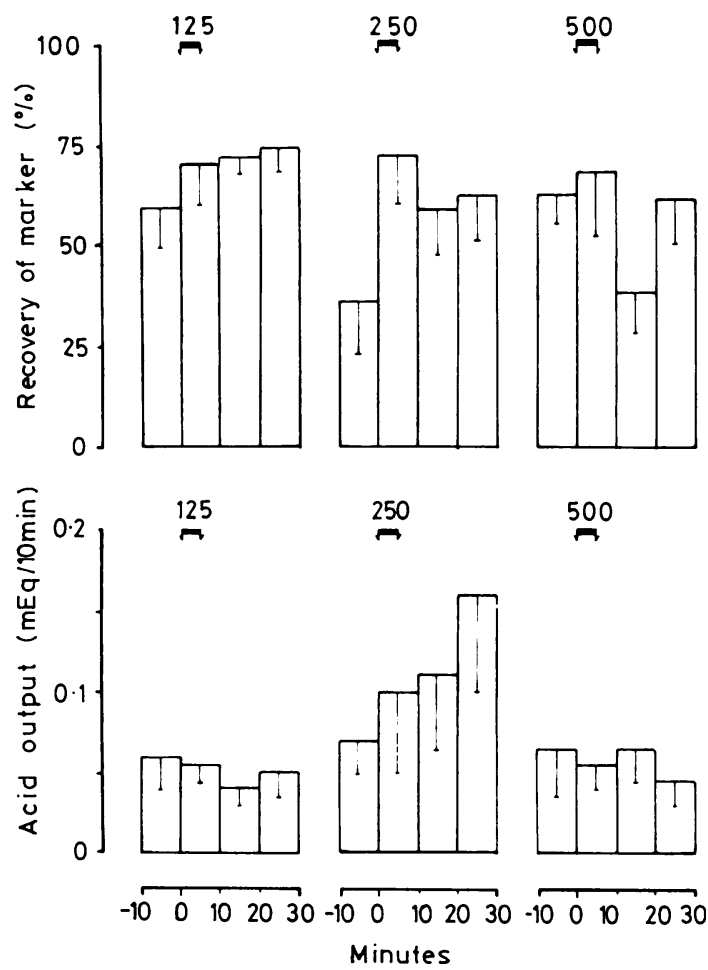

Fig. 2 Mean $\pm S E$ percent marker recovered (upper panel) and acid output (lower panel) in six antrectomised dogs submitted to gastric distention with a balloon inflated with 125, 250, and $500 \mathrm{ml}$ of air. Each distention lasted for five minutes. The gastric effluent was collected as 10 minute fractions and analysed for volume, phenol red concentration, and acid concentration.

$125 \mathrm{ml}$ of air $\left(39 \cdot 3 \pm 4 \cdot 0\right.$ to $\left.49 \cdot 6 \pm 7 \cdot 6 \mathrm{pg} \mathrm{ml}^{-1}\right)$ was not significant. A limited, but significant rise of peripheral VIP was observed after the $500 \mathrm{ml}$ distention, from $22 \cdot 3 \pm 4 \cdot 3$ to $28.0 \pm 5.0 \mathrm{pg} \mathrm{ml}^{-1}$ at five minutes $(\mathrm{P}<0.05)$. Except for two 10 minute periods, respectively, before and after the 250 and $500 \mathrm{ml}$ distentions (Fig. 2), the recovery of phenol red in the gastric effluent was in the range of $60-75 \%$ (Fig. 2). Under the conditions of this experiment, none of the distention volumes tested induced a significant variation of acid output (Fig. 2).

In the antrectomised dogs submitted to irrigation of the fundic pouch with $0.15 \mathrm{M} \mathrm{HC1}$, the mean plasma VIP concentration in the portal vein during the 15 minute basal period was $36 \cdot 2 \pm 8.9 \mathrm{pg} \mathrm{ml}^{-1}$. No significant variation was observed when distending the pouch with 10 or $20 \mathrm{~cm}$ pressure, but $40 \mathrm{~cm}$ of water pressure induced a significant rise to a peak of $59.8 \pm 12.4 \mathrm{pg} \mathrm{ml}^{-1}(\mathrm{P}<0.05$, Fig. 3).

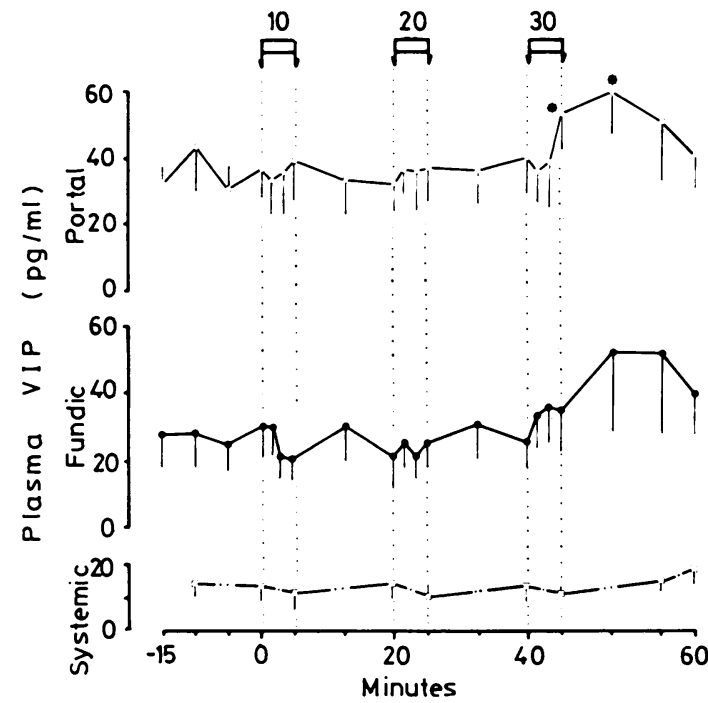

Fig. 3 Mean \pm SE plasma VIP concentrations in portal vein (upper panel), fundic vein (middle panel), and femoral vein (lower panel) in five anaesthetised dogs submitted to sequential distention of an acute fundic pouch at 10,20, and $40 \mathrm{~cm}$ of water pressure with $0.15 \mathrm{M}$ hydrochloric acid. ${ }^{*} \mathrm{P}<0.05$.

The same pattern was observed in the plasma drawn from the fundic vein, but the rise induced by the $40 \mathrm{~cm}$ distention (from basal $29 \cdot 2 \pm 7 \cdot 3$ to peak $53 \cdot 2 \pm 22 \cdot 4 \mathrm{pg} \mathrm{ml}^{-1}$ ) did not attain statistical significance, probably because of the wide variations in VIP among dogs. The systemic concentration, measured before and after each distention period, was not affected by any of the pressures applied.

\section{Discussion}

The present results indicate that transient distention of the proximal stomach in dogs evokes a significant release of VIP in portal blood, and that this response is not suppressed by luminal acidification.

In conscious animals, VIP was released in significant quantities at distentions of 250 and $500 \mathrm{ml}$, but its release in response to $125 \mathrm{ml}$ was not significant. The technical problems involved in handling, simultaneously, portal and peripheral catheters in conscious dogs made it impossible to test the variations of plasma VIP at intervals shorter than five minutes, so that increases greater than reported possibly went undetected in the present study. From the results obtained under these conditions, there was no clear correlation between distention volume and VIP response, as seen in Fig. 1, a finding that has been confirmed in subsequent unpublished experiments performed in dogs 
with antral pouches. The VIP release induced by distending the proximal stomach may thus be an all-or-none response, possibly mediated by long vagovagal or short intramural reflexes, as for the acid response to distention in the same species. ${ }^{12}$ The fact that the first significant response was observed with a moderate distention volume strongly suggests that distention of the proximal stomach is a physiological releasing factor for VIP in dogs. This is indirectly supported by the observation of a significant increase of portal VIP concentration (about $30 \mathrm{pg} / \mathrm{ml}$ ) in the same antrectomised animals five minutes after ingestion of their regular $400 \mathrm{ml}$ meal (unpublished studies).

The possible mechanisms of the distentioninduced VIP release could not be full elucidated in the present set of experiments. In the group of conscious dogs, the recovery of phenol red infused constantly into the stomach was essentially unaffected by the short distention periods, indicating that the VIP response was not simply reflecting an increased load of gastric contents to the duodenum. Whether the release was attributable to variations of intragastric $\mathrm{pH}$ due to the stimulatory effect of proximal gastric distention on acid secretion in $\operatorname{dogs}^{12}$ was apparently ruled out by the fact that none of the present distention volumes, applied for five minutes in conscious animals, evoked any significant variation of acid output. As small changes of juxtamucosal $\mathrm{pH}$ could have been overlooked, however, the effect of distention of an acute fundic pouch was tested against luminal acidification in anaesthetised animals. Although both anaesthesia and surgical trauma probably altered the sensitivity of the VIP-producing sites in the digestive tract, the results then obtained indicate that the VIPreleasing effect of proximal gastric distention is retained when any variation of the juxtamucosal $\mathrm{pH}$ is obscured by luminal acidification. Whether the peptide release was triggered directly by mechanical receptors located in the gastric wall, or indirectly by the motor response to distention, remains to be investigated. As intestinal ischaemia was shown to evoke a sharp release of VIP into the portal stream,,$^{13}$ an additional mechanism to be tested would be the transient reduction of mucosal blood flow possibly resulting from the rise of intragastric pressure.

In the group of anaesthetised animals, the variations of plasma VIP concentration were tentatively studied both in the portal vein and in a vein draining the acute fundic pouch. Though the increase of plasma VIP at the later site after distention under $40 \mathrm{~cm}$ of water pressure did not reach significance, contrasting with the steady concentrations recorded both in portal and fundic vein during the first part of the experiment, it provides circumstantial evidence that at least part of the VIP detected in the portal vein originated from the fundic pouch itself.

The physiological importance of the distentioninduced VIP response remains speculative. When given exogenously, the peptide displays relaxing properties on the digestive smooth muscle, ${ }^{14} 15$ but the changes in plasma VIP levels induced by such infusions, appear to be supraphysiological. ${ }^{16}$ This, however, leaves open the possibility that VIP has a local role as neurotransmitter or as paracrine substance, so that the rise of portal VIP found in this study might reflect the simple overflow of the peptide released in the tissues. Additional studies with VIP in amounts comparable with those found in portal plasma are needed to more clearly assess the effects of the peptide on the motor, vasoactive, and secretory mechanisms in the digestive tract.

In all mammals studied, VIP is broadly distributed in the gastrointestinal tract. ${ }^{24}$ After the demonstration of a significant release of the peptide by mechanical stimulation of the oesophagus and of the intestinal mucosa in anaesthetised cats, ${ }^{9}$ the present results suggest that mechanical stimuli may release VIP from most parts of the gastrointestinal tract. In addition, because of the experimental conditions chosen here, they indicate that proximal gastric distention is a physiological VIPreleasing mechanism operating in dogs.

\section{References}

${ }^{1}$ Mutt V, Said SI. Structure of the porcine vasoactive intestinal octacosapeptide. Eur J Biochem 1974; 42: 581-9.

${ }^{2}$ Larsson LI, Fahrenkrug J, Schaffalitzky de Muckadell $\mathrm{OB}$, Sundler F, Håkanson R, Rehfeld JF. Localization of vasoactive intestinal polypeptide (VIP) to central and peripheral neurons. Proc Natl Acad Sci USA 1976; 73: 3197-200.

${ }^{3}$ Larsson LI, Fahrenkrug J, Schaffalitzky de Muckadell OB. Vasoactive intestinal polypeptide occurs in nerves of the female genitourinary tract. Science 1977; 197 : 1374-5.

${ }^{4}$ Bryant MG, Polak JM, Modlin I, Bloom SR, Albuquerque RH, Pearse AGE. Possible dual role for vasoactive intestinal peptide as gastrointestinal hormone and neurotransmitter substance. Lancet 1976; 1 : 991-3.

${ }^{5}$ Schaffalitzky de Muckadell OB, Fahrenkrug J, Holst JJ, Lauritsen KB. Release of vasoactive intestinal polypeptide (VIP) by intraduodenal stimuli. Scand J Gastroenterol 1977; 12: 793-9.

${ }^{6}$ Bloom SR, Mitchell SJ, Greenberg GR, Christofides S, Domschke W, Domschke S, Mitznegg P, Demling L. Release of VIP, secretin and motilin after duodenal acidification in man. Acta Hepatogastroenterol (Stutt) 1978; 25: 365-8. 
'Ebeid AM, Soeters PB, Murray P, Fischer JE. Release of vasoactive intestinal peptide (VIP) by intraluminal osmotic stimuli. J Surg Res 1977; 23: 25-30.

${ }^{8}$ Ebeid AM, Murray P, Soeters PB, Fischer JE. Release of VIP by calcium stimulation. Am J Surg 1977; 133 $140-4$.

${ }^{9}$ Fahrenkrug J, Haglund U, Jodal M, Lundgren $\mathrm{O}$, Olbe L, Schaffalitzky de Muckadell OB. Nervous release of vasoactive intestinal polypeptide in the gastrointestinal tract of cats: Possible physiological implications. J Physiol (Lond) 1978; 284: 291-305.

${ }^{10}$ Schedl HP. Use of polyethylene glycol and phenol red as unabsorbed indicators for intestinal absorption studies in man. Gut 1966; 7: 159-63.

${ }^{11 G u z m a n ~ S, ~ C h a y v i a l l e ~ J-A, ~ B a n k s ~ W A, ~ R a y f o r d ~ P L, ~}$ Thompson JC. Effect of vagal stimulation on pancreatic secretion and on blood levels of gastrin, cholecystokinin, secretin, vasoactive intestinal peptide, and somatostatin. Surgery 1979; 86: 329-36.

${ }^{12}$ Grossman MI. Secretion of acid and pepsin in response to distension of vagally innervated fundic gland area in dogs. Gastroenterology 1962; 42: 718-21.
${ }^{13}$ Modlin IM, Bloom SR, Mitchell SJ. Plasma vasoactive intestinal polypeptide (VIP) levels and intestinal ischemia. Experientia 1978; 34: 535-6.

${ }^{14}$ Rattan S, Said SI, Goyal RK. Effect of vasoactive intestinal polypeptide (VIP) on the lower esophageal sphincter pressure. Proc Soc Exp Biol Med 1977; 155: 40-3.

${ }^{15}$ Said SI, Makhlouf GM. Vasoactive intestinal polypeptide: Spectrum of biological activity. In: Chey WY, Brooks FP, eds. Endocrinology of the gut Thorofare, NJ: Charles B Slack Inc, 1974: 88-102.

${ }^{16}$ Domschke W, Lux G, Domschke S, Strunz U, Bloom SR, Wünsch E. Effects of vasoactive intestinal peptide on resting and pentagastrin-stimulated lower esophageal sphincter pressure. Gastroenterology 1978; 75: 9-12.

${ }^{17}$ Chayvialle J-A, Miyata M, Rayford PL, Thompson JC. Effect of fundic distension on vasoactive intestinal peptide in dogs (abstract). Scand J Gastroenterol 1978; 13: Suppl 49: 38 